\title{
Genome-wide host responses against infectious laryngotracheitis virus vaccine infection in chicken embryo lung cells
}

\author{
Jeongyoon Lee ${ }^{1,2}$, Walter G Bottje $e^{1,2}$ and Byung-Whi Kong ${ }^{1,2^{*}}$
}

\begin{abstract}
Background: Infectious laryngotracheitis virus (ILTV; gallid herpesvirus 1) infection causes high mortality and huge economic losses in the poultry industry. To protect chickens against ILTV infection, chicken-embryo origin (CEO) and tissue-culture origin (TCO) vaccines have been used. However, the transmission of vaccine ILTV from vaccinated- to unvaccinated chickens can cause severe respiratory disease. Previously, host cell responses against virulent ILTV infections were determined by microarray analysis. In this study, a microarray analysis was performed to understand host-vaccine ILTV interactions at the host gene transcription level.

Results: The $44 \mathrm{~K}$ chicken oligo microarrays were used, and the results were compared to those found in virulent ILTV infection. Total RNAs extracted from vaccine ILTV infected chicken embryo lung cells at 1, 2, 3 and 4 days post infection (dpi), compared to $0 \mathrm{dpi}$, were subjected to microarray assay using the two color hybridization method. Data analysis using JMP Genomics 5.0 and the Ingenuity Pathway Analysis (IPA) program showed that 213 differentially expressed genes could be grouped into a number of functional categories including tissue development, cellular growth and proliferation, cellular movement, and inflammatory responses. Moreover, 10 possible gene networks were created by the IPA program to show intermolecular connections. Interestingly, of 213 differentially expressed genes, BMP2, C8orf79, F10, and NPY were expressed distinctly in vaccine ILTV infection when compared to virulent ILTV infection.

Conclusions: Comprehensive knowledge of gene expression and biological functionalities of host factors during vaccine ILTV infection can provide insight into host cellular defense mechanisms compared to those of virulent ILTV.
\end{abstract}

\section{Background}

Avian infectious laryngotracheitis virus (ILTV), named as a Gallid herpesvirus 1, is a member of the Iltovirus genus, Alphaherpesvirinae subfamily, and Herpesviridae family. ILTV has a linearized dsDNA genome of approximately $150 \mathrm{~kb}$ in size which contains unique long (UL) and unique short (US) sequences flanked by inverted repeat (IR) and terminal repeat (TR) sequences $[1,2]$. The genome encodes 80 predicted viral protein open reading frames (ORFs). ILTV infection causes respiratory disease symptoms in chickens, pheasants, partridges, and peafowl $[3,4]$. Clinical signs include

\footnotetext{
* Correspondence: bkong@uark.edu

'Department of Poultry Science, Division of Agriculture, POSC O-404, 1260

West Maple, Fayetteville, AR 72701, USA

Full list of author information is available at the end of the article
}

extension of the neck, gasping, gurgling, rattling, and coughing of clotted blood [5]. ILTV usually causes a reduction in egg production and variable mortality ranging from 5 to $70 \%$, and can cause severe economic losses in the poultry industry [6].

Two types of commercial live attenuated vaccines, chicken embryo origin (CEO) and tissue culture origin (TCO), have been widely used to immunize chicken flocks against ILTV [6,7]. However, it was found that live vaccines infect the nervous system similarly to virulent ILTV infections, and could possibly induce vaccinal laryngotracheitis (VLT) by transmission to unvaccinated birds [8-10]. Moreover, global ILTV outbreaks are mostly associated with CEO vaccines [11-13] and the genomic- and antigenic characteristics between virulent and vaccine ILTV are very similar [6].

C Biomed Central

(c) 2012 Lee et al; licensee BioMed Central Ltd. This is an Open Access article distributed under the terms of the Creative Commons Attribution License (http://creativecommons.org/licenses/by/2.0), which permits unrestricted use, distribution, and reproduction in any medium, provided the original work is properly cited. 
Microarray analysis has become popular, along with the recent development of a RNA-seq (RNA sequencing) technique using next-generation sequencing, to analyze comprehensive gene expression in different biological conditions. Microarrays have been performed intensively to investigate host gene transcriptional responses to infection by various viruses such as hepatitis C virus (HCV) [14], rice dwarf virus (RDV) [15], influenza virus [16], herpesvirus saimiri (HVS) [17], human immunodeficiency virus (HIV) $[18,19]$, Japanese encephalitis virus (JEV) [20,21], chicken anemia virus (CAV) [22], human cytomegalovirus (hCMV) [23], Epstein-Barr virus (EBV) [24], infectious laryngotracheitis virus (ILTV) [25], varicella-zoster virus (VZV) [26], alphaherpesvirus [27], Marek's disease virus (MDV) [28], herpes simplex virus type 1 (HSV-1) [29], even in vaccine strains including recombinant flavivirus [30], west nile/dengue 4 virus [31], and dengue virus [32].

Previously, we studied the differential gene expression of host responses against virulent ILTV infection in cultured primary chicken embryo lung cells using microarray analysis [25]. To compare and contrast host responses to infection of vaccine ILTV to those of virulent ILTV infection, primary chicken embryo lung cells were infected with live attenuated CEO vaccines and host gene expression during a four day period post infection was determined using $44 \mathrm{~K}$ chicken oligo microarrays in the present study.

\section{Results and discussion}

Profiling of differentially expressed host genes in vaccine ILTV infection

Primary chicken embryo lung cells at passage 1 were infected with 3 vaccination doses of a live fowl laryngotracheitis vaccine, which is widely used in the poultry industry. The infected cells were subjected to analysis for cytopathic effects and virus infection validation at 1 , 2,3 and 4 days post infection (dpi). Although weak cytopathic effects (e.g. cell rounding, aggregation and syncytia) were observed at certain locations of plates at 1 and $2 \mathrm{dpi}$, infected cells began to recover by $3 \mathrm{dpi}$, and no cytopathic effects were observed at 4 dpi (Figure 1A). To verify the infection of vaccine ILTV, the expression of ILTV viral RNA was determined and genes of UL35 encoding a small capsid protein and US5 encoding an envelop glycoprotein J (gJ) were shown to progressively increase their expression post infection though US5 expression began to be detected from 2 dpi (Figure 1B).

In the $44 \mathrm{~K}$ microarray assay, two approaches to avoid possible hidden dye effects were used: the use of RNA Spike-in controls synthesized from the Adenovirus E1A transcriptomes containing different concentrations of dye in each set [33] and the dye-swap in two of four total replicates. No significant dye effects were detected in all microarray slides (data not shown). Data analysis using one-way ANOVA with the JMP Genomics 5.0 and a 2 fold or greater cut off value revealed that 933 genes were differentially expressed at 4 different dpi time points following vaccine ILTV infection (Additional file 1 ). When these 933 differentially expressed genes were subjected to the bioinformatics study using Ingenuity Pathways Analysis (IPA, Ingenuity ${ }^{\circledR}$ Systems, http:// www.ingenuity.com) to generate the gene networks and functional annotations, 213 genes were recognized as mapped IDs (functionally known genes) by the IPA program (Additional file 2) and subjected to further bioinformatics analysis.

\section{Quantitative reverse transcription-PCR (qPCR)}

To validate the microarray results, expression of 18 of the 933 differentially expressed genes was subjected to qPCR using the same RNA samples as those used in the microarray, and gene specific primer sets (Tables 1, 2). Of the 18 genes tested, the expression pattern for 12 genes completely matched the microarray data at four dpi time points. The expression pattern for the remaining 6 genes also qualitatively matched to microarray data, though they were not quantitatively matched (Table 2). With the comparison of the spike-in controls, qPCR results indicated that the microarray data in this experiment were valid to determine host gene expression responses against vaccine ILTV infection.

The gene expression levels of microarray were presented by $\log _{2}$ fold changes, whereas those of qPCR were indicated by $-\Delta \Delta \mathrm{Ct}$ that are comparable to the $\log _{2}$ fold change values in microarray

\section{Biological functions of differentially expressed genes}

Using the IPA program, the subset of 213 mapped genes were categorized into 75 biologically functional groups, and the top 20 groups associated with a greatest number of genes, are shown in Figure 2. The 20 functional groups are mostly related to tissue development, cellular growth and proliferation, organismal development, cell death, cellular development, cellular movement, and inflammatory responses.

\section{Top 10 differentially expressed genes}

Of 213 genes with known functions with mapped IDs, the top 10 most differentially expressed genes in ILTV vaccine infection were selected based on differences of standard deviation (SD) among all four dpi time points (Figure 3). The 10 most differentially expressed genes are involved in functions of reduced inflammatory responses, stimulation of cell proliferation, suppression of apoptosis, and promotion of cell-to-cell interactions. The general function and possible roles of these 


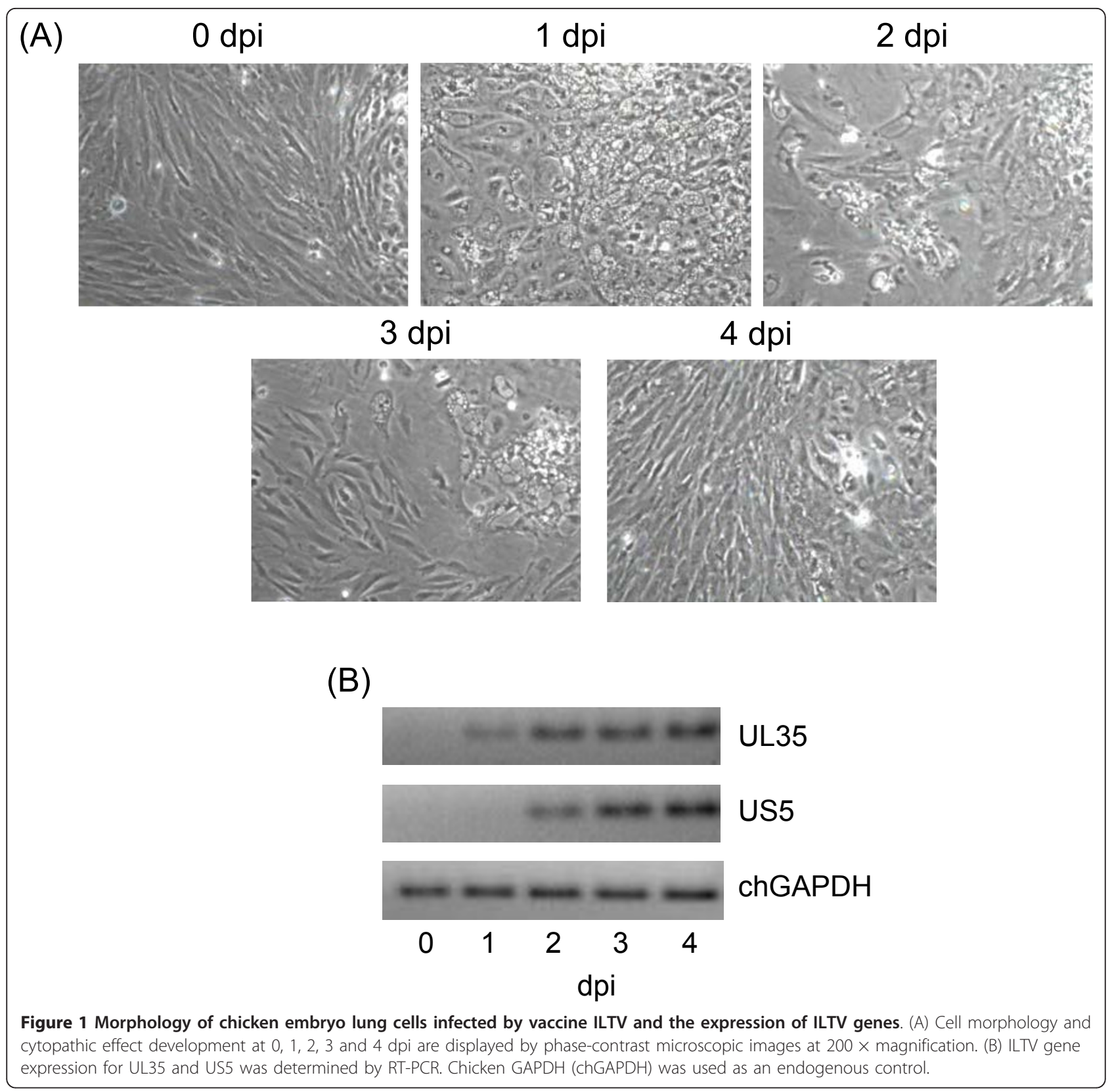

differentially expressed genes during ILTV infection are outlined in Table 3.

The C1q and tumor necrosis factor related protein 3 [C1QTNF3; also known as (a. k. a.) CTRP3] is known to stimulate ERK1/2 and p38 MAPK [58]. C1QTNF3 expression was elevated from 2 to 4 dpi (Figure 3). In addition, cartonectin (an adipokine of the CTRP3 family) helps reduce inflammation by suppressing IL6 and TNF production and NF- $\kappa \mathrm{B}$ signaling [59-61]. IL6, one of several cytomegalovirus secreted cytokines, enhances the survival of endothelial cells by blocking caspase 3 and caspase 7-mediated apoptosis [62].
CTRP3 could also accelerate embryonic growth and may contribute to a high feed efficiency phenotype in broilers [63]. Thus, the continuous increase of CTRP3 expression from 2 to $4 \mathrm{dpi}$ during ILTV vaccine infection suggests the suppression of cellular factors related to inflammation and the promotion of cell recovery after the initial cytopathic effect that was exhibited in embryonic lung cells on 1dpi.

Aquaporin 5 (AQP5) expression, a water channel protein and part of the small integral membrane protein family, was elevated on $1 \mathrm{dpi}$, but decreased at 2- and 4dpi (Figure 3). A deficiency AQP5 was shown to 
Table 1 Primers for qPCR

\begin{tabular}{lll}
\hline GenBank & Forward Primer & Reverse Primer \\
\hline AB109635 & GGCACCAACTGCTACCACA & GCTGCAAGAGCTGCCATTAG \\
\hline AF505881 & CCAGCTACATCTCCCACCTG & TCTGTTGGGCTGGGAGTC \\
\hline BX932962 & GTACAACCACGTTGGGCAGA & CTCTCGCGTTCCTTGAGG \\
\hline BX931297 & TTGTGGCCTACCCCAGATGT & GGATGGGACTTCCAGAGCA \\
\hline BX931599 & CTGTTCCTGACCGCAGTTC & AGCACAAACTCCGCCATTT \\
\hline BX933478 & CCTGTGCAAGGTGTCCAGTG & CCCAATGGCCATACAGTCA \\
\hline BX933728 & GCAAAGCACCATCCCAATA & TAT TGAGGCGCTGACTCCTG \\
\hline BX933888 & CTGGGATCCCTCCAGAGCTA & CCATTCACTGGAGCACCAAA \\
\hline BX935456 & CGAGGCCATCAACTTCCTC & TCCACATGACGCACATACCC \\
\hline BX936211 & CCAGCTGTCCTCCTTGGAAT & AGGGAGAGGAAGACGTGCTG \\
\hline CR352775 & GGCCTTGAATGACCATCATGT & AACAGCAGCAGGAACAGTGC \\
\hline CR385566 & CGCGCTCTACGACTACATGC & CTGGGTGGTGATCTCGGTCT \\
\hline D87992 & TGCAGCACTGAGACCTGGAT & CAGTTGCTGCGGATGAAGTC \\
\hline M60853 & TITGGCTACCAGTCCAGCA & TTCGCAAGTGTCCCCAGTA \\
\hline M64990 & TGCTCCCCTGAGTACTGGAA & GCCTCTGTGGGTTCAGGATT \\
\hline M80584 & TCCCACTGAGCAGCTTCTGTA & CCAGAGAGATATCCGCAGCA \\
\hline M87294 & GGTGCTGACTTCGCCTTGT & GCCTGGTGATGAGGTTGATG \\
\hline X87609 & CCACCTGAGAAAAGCACCT & ACATCGACCTCTGCCAACCT \\
\hline
\end{tabular}

exacerbate lung injury by the infection of Pseudomonas aeruginosa [64]. Down-regulation of AQP5 increases proliferation and migration of human corneal epithelial (CEP117) cell line [65]. Adenovirus infection to mouse lung caused the down-regulation of AQP5 gene

Table 2 Validation of gene expression between microarray and qPCR

\begin{tabular}{llllll}
\hline GenBank & \multirow{2}{*}{ Symbol } & \multicolumn{4}{l}{ Fold Change (Microarray/qPCR) } \\
\cline { 3 - 6 } & & Day $\mathbf{1}$ & Day 2 & Day 3 & Day 4 \\
\hline BX932962 & SLC37A2 & $1.2 / 1.3$ & $2.1 / 2.6$ & $3.3 / 3.7$ & $3.9 / 4.5$ \\
\hline M60853 & THBS2 & $1.5 / 1.8$ & $2.0 / 2.5$ & $2.8 / 2.8$ & $3.3 / 3.3$ \\
\hline BX933888 & C1QTNF3 & $-0.2 / 0.1$ & $1.2 / 2.0$ & $1.9 / 2.5$ & $2.7 / 3.4$ \\
\hline BX933728 & CAPSL & $2.3 / 3.0$ & $2.6 / 3.7$ & $3.2 / 4.3$ & $3.5 / 4.4$ \\
\hline BX931297 & CYTL1 & $1.0 / 1.7$ & $1.4 / 2.8$ & $2.7 / 4.2$ & $2.9 / 4.4$ \\
\hline CR352775 & ALDOB & $0.7 / 1.1$ & $1.0 / 1.7$ & $2.1 / 2.2$ & $2.7 / 2.5$ \\
\hline BX933478 & MXRA5 & $0.8 / 1.5$ & $1.7 / 3.0$ & $2.5 / 3.7$ & $3.0 / 4.4$ \\
\hline BX935456 & EGLN3 & $-2.7 /-2.0$ & $-2.3 /-1.9$ & $-1.7 /-1.4$ & $-1.3 /-0.9$ \\
\hline BX931599 & VIPR2 & $1.7 / 2.0$ & $2.3 / 2.9$ & $2.9 / 3.6$ & $3.1 / 5.1$ \\
\hline CR385566 & CLEC3B & $0.2 / 1.0$ & $0.4 / 2.2$ & $1.3 / 2.4$ & $1.4 / 3.1$ \\
\hline M87294 & NPY & $-0.4 /-0.3$ & $-0.9 /-0.6$ & $-1.5 /-0.9$ & $-1.7 /-1.3$ \\
\hline M80584 & LUM & $1.2 / 1.6$ & $1.5 / 2.3$ & $1.9 / 2.5$ & $2.5 / 3.2$ \\
\hline M64990 & PTGS2 & $-0.6 /-0.6$ & $-0.8 /-0.3$ & $-0.2 /-0.4$ & $0.7 / 1.2$ \\
\hline AB109635 & HMGCR & $0.4 / 0.4$ & $0.2 / 0.6$ & $-0.5 /-0.3$ & $-0.9 /-0.6$ \\
\hline BX936211 & TMEM116 & $0.0 / 0.0$ & $-0.3 / 0.3$ & $-0.3 /-0.1$ & $-1.3 /-0.7$ \\
\hline X87609 & FST & $1.3 / 1.0$ & $0.6 / 1.2$ & $0.6 / 0.6$ & $-0.3 / 0.2$ \\
\hline D87992 & ANPEP & $-0.1 /-1.2$ & $-0.5 / 0.5$ & $-0.6 / 0.4$ & $-1.4 /-0.2$ \\
\hline AF505881 & SCX & $1.1 / 0.2$ & $1.4 /-0.6$ & $1.8 / 0.1$ & $2.3 /-0.6$ \\
\hline
\end{tabular}

expression [66]. Thus, the slight down-regulation of AQP5 gene expression in vaccine ILTV infection in from 2 to 4 dpi may be associated with the reduced cytopathic effect and cell recovery.

Cholecystokinin (CCK) was down-regulated in lung cells between 2 and 4 dpi (Figure 3 ). CCK is a peptide hormone of the gastrointestinal system that is important in fat digestion [67]. CCK induces apoptosis by stimulating death signaling pathways in rat pancreatic acinar cells, including caspase activation, cytochrome $\mathrm{C}$ release, and mitochondrial depolarization [68]. Thus, the downregulation of CCK expression in vaccine ILTV infected cells may suppress apoptosis, resulting in weak cytopathic effects.

\section{Gene networks}

Network analysis by IPA was used to draw connections between interacting focus molecules. Of the 10 networks that were generated, the top 4 networks were identical among all four dpi, which may be due to the fact that the algorithms of the IPA program generate a network by considering fold change values and p-values of focus molecules in addition to their biological functions. The lists, top functions, and the most focused molecules of all four networks are shown in Additional file 3, and the drawings of interacting molecules in each network during the time course of all dpi are displayed in Additional file 4 .

The most interactive network (network \#1) at $1 \mathrm{dpi}$ is presented in Figure 4. Similar differential expression levels for focus molecules in network \#1 are shown at all four dpi during ILTV vaccine infection and the top functions related to genes in this network include free radical scavenging, lipid metabolism, and small molecule biochemistry. Several secreting proteins such as FIGF [c-fos induced growth factor; a.k.a vascular endothelial growth factor D (VEGF-D)], PDGFC (platelet derived growth factor C), TNFSF15 (tumor necrosis factor superfamily member 15), and CRH (corticotropin releasing hormone) in network \#1 are closely associated with the activation of the ERK1/2 signaling pathway [69-72]. Additional cellular factors, including MGAT3 (mannosyl glucosaminyltransferase 3), HS6ST1 (heparin sulfate 6O-sulfotransferase 1), and CIRBP (cold inducible RNA binding protein), that activate ERK $1 / 2$ by increased phosphorylation are also upregulated in vaccine ILTV infection [73-75]. These results indicate that the mitogenic signaling pathway may be activated by increased phosphorylation of ERK $1 / 2$ in vaccine ILTV infection, resulting in weak cytopathic effects that facilitate the recovery of cellular proliferation capabilities of embryonic lung cells during vaccine ILTV infection. In addition, several enzymatic antioxidants in lung cells that would reduce cellular oxidative stress included SOD3 


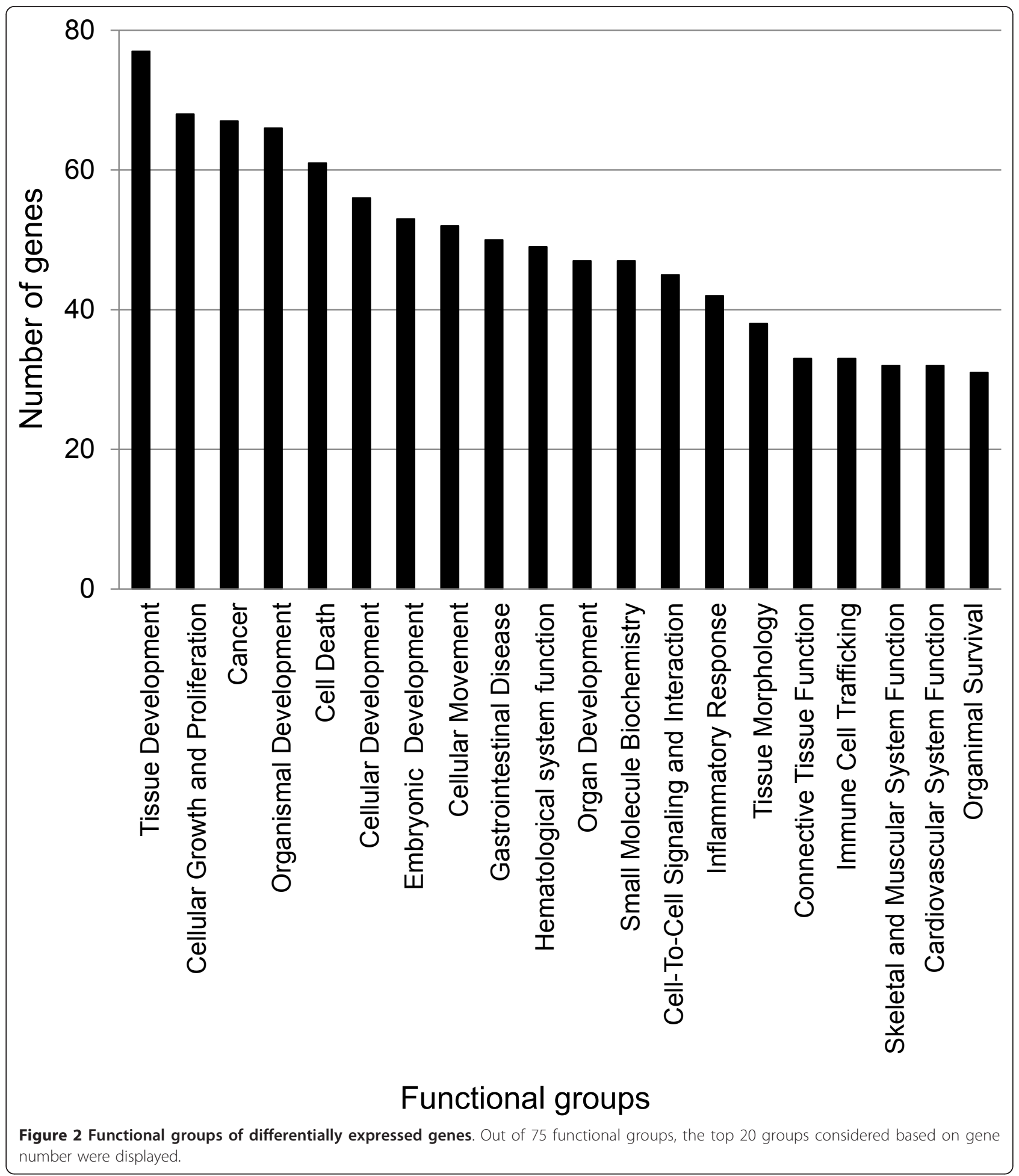

(superoxide dismutase 3, extracellular), GPX7 (glutathione peroxidase 7), and GSTs (glutathione S tranferases; GST-A3, -T1, -A4) were also assigned to network \#1. This up-regulation of these enzymatic antioxidants would serve to protect cells from oxidant- mediated cell death. These results concur with a previous report of enhanced endogenous antioxidant protection during vaccine ILTV infection and attenuation of cell death [76]. Focus molecules found in network \#1 can be summarized by the following functions: 


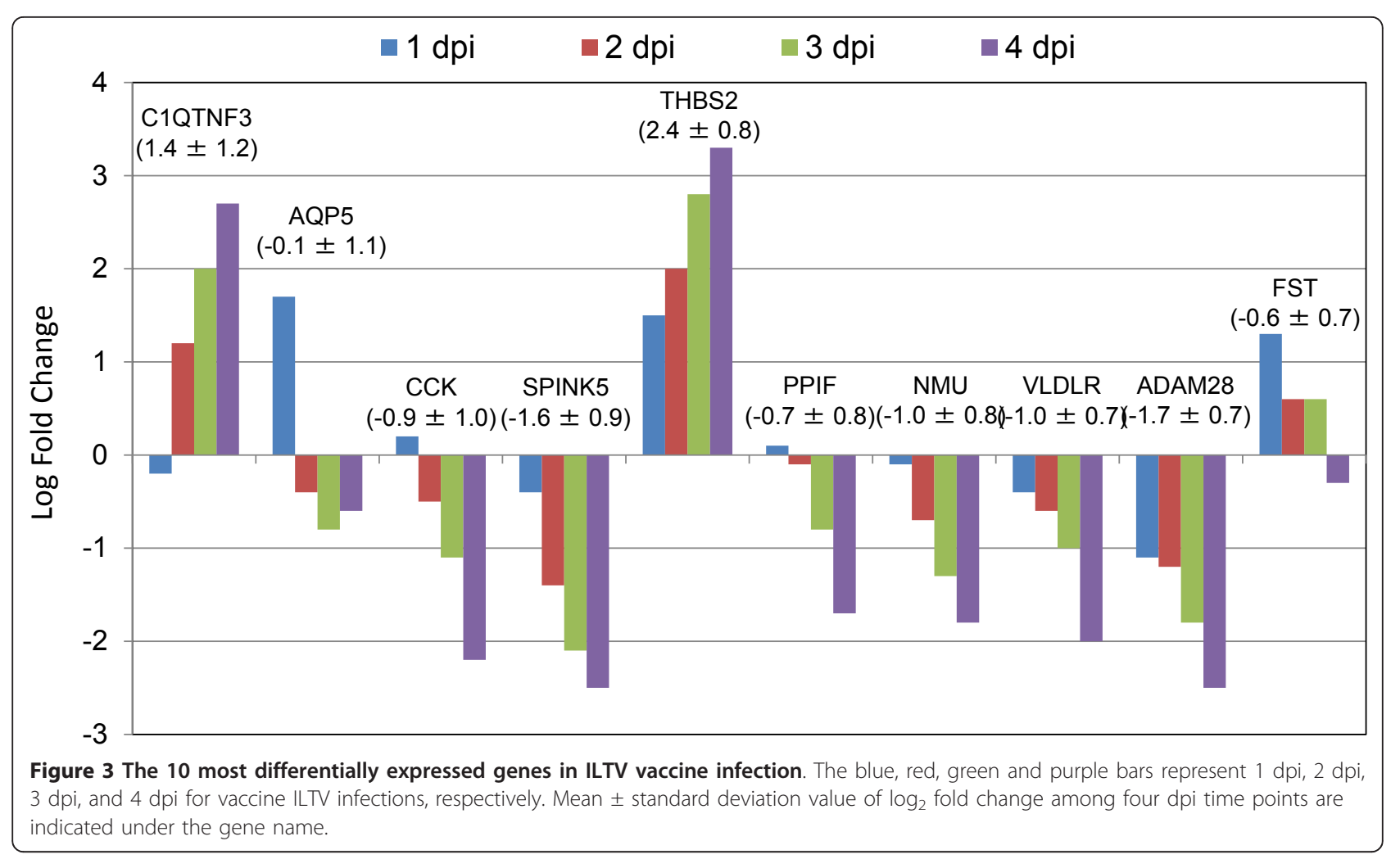

stimulation of various secreting proteins, inhibition of the cell death pathway, and attenuation of oxidative stress.

Functional interpretation of other networks is described in Additional files 3 and 4.

\section{Comparison of host responses of virulent strain and vaccine ILTV infection}

Previously, we reported 273 differentially expressed chicken genes mapped by the IPA program for virulent ILTV infection and the analysis of the functions and molecular networks of these genes [25]. To find host cellular mechanisms common to both virulent strain and vaccine ILTV infection, the 213 differentially expressed genes that responded to vaccine ILTV infection in the present study were compared to the 273 differentially expressed genes found in the previous virulent ILTV infection study. The results showed that 25 genes overlapped in both virulent strain and vaccine ILTV infections. Of these 25 genes, 21 showed a similar differential expression pattern as found in the virulent ILTV infection at 1 and $3 \mathrm{dpi}$ (the GenBank accession, gene symbol and gene name are listed in Additional file 5). Interestingly, 4 of 25 genes were regulated in the distinct direction for expression patterns at 1 or $3 \mathrm{dpi}$ between virulent and vaccine ILTV in the present study (see Figure 5). Those genes included bone morphogenetic protein 2 (BMP2, AY237249), chromosome 8 open reading frame 79 (C8orf79, CR390951), coagulation factor $\times($ F10, D00844), and neuropeptide $Y$ (NPY, M87294).

Bone morphogenetic proteins (BMPs), as members of the transforming growth factor beta (TGF $\beta$ ) superfamily, are involved in various cellular functions including cell type specification, differentiation, pluripotency, apoptosis, proliferation, and tissue morphogenesis [77]. Deregulation of BMP signaling is also implicated in disease states including cancer [78]. Though the functional role of BMP in ILTV infection is unknown, BMPs including BMP2 were found to mediate herpesviral reactivation found in the EBV positive cell line [79]. The expression and secretion of BMP2 was regulated by HIV proteins in differentiating mesenchymal stem cells [80]. Expression of BMP2 in both virulent and vaccine ILTV infections increased at $1 \mathrm{dpi}$ and the increased expression level in vaccine ILTV infection was maintained until $3 \mathrm{dpi}$, while the expression in virulent ILTV was not changed at 3dpi (Figure 5). The continuous increase of BMP2 expression during ILTV vaccine infection may play a homeostatic role in maintaining cellular morphology against virus infection.

Neuropeptide Y (NPY) involves multiple cellular mechanisms related to both virus entry into the central nervous system (CNS) and virus-induced neurological 
Table 3 Functions of the 10 most differentially expressed genes in ILTV vaccine infection

\begin{tabular}{|c|c|}
\hline Symbol & Functions \\
\hline $\begin{array}{l}\text { C1QTNF3 } \\
\text { (CTRP3) }\end{array}$ & $\begin{array}{l}\text { - C1q and tumor necrosis factor related protein 3, a. k. a. CTRP3. } \\
\text { - Functions are described in the Result and Discussion. }\end{array}$ \\
\hline AQP5 & $\begin{array}{l}\text { - Aquaporin 5, a water channel protein. } \\
\text { - Functions are described in the Result and Discussion. }\end{array}$ \\
\hline CCK & $\begin{array}{l}\text { - Cholecystokinin } \\
\text { - Functions are described in the Result and Discussion. }\end{array}$ \\
\hline SPINK5 & $\begin{array}{l}\text { - Serine peptidase inhibitor, Kazal type } 5 \text { or chicken ovomucoid } \\
\text { - Lymph-epithelial Kazal-type-related inhibitor (LEKTI). } \\
\text { - Suppresses cellular functions related to inflammation in human primary keratinocytes (HK) [34]. } \\
\text { - Down-regulation of SPINK5 at all dpi may support the reduced cell death caused by vaccine ILTV infection. }\end{array}$ \\
\hline THBS2 & $\begin{array}{l}\text { - Thrombospondin 2, a potent inhibitor of tumor growth and angiogenesis and a matricellular glycoprotein which mediates cell-to- } \\
\text { cell interaction [35]. } \\
\text { - Functions in angiogenesis in patients with early-stage non-small cell lung cancer [36], and wound healing and development of } \\
\text { exuberant granulation tissue in horses [37]. } \\
\text { - Up-regulation of THBS2 in vaccine ILTV infection may function in virus spread in infected cells. }\end{array}$ \\
\hline PPIF & $\begin{array}{l}\text { - Peptidylprolyl isomerase F, one of the peptidyl-prolyl cis-trans isomerase (PPlase) family proteins and a member of the } \\
\text { mitochondrial permeability transition (PT) pore in the inner mitochondrial membrane. } \\
\text { - Stimulates the cis-trans isomerization of proline imidic peptide bonds in oligopeptides and accelerate the folding of proteins } \\
{[38,39] \text {. }} \\
\text { - Apoptosis and necrosis of cells were induced by the activation of the PT pore [40-42]. } \\
\text { - Down-regulation of PPIF genes in vaccine ILTV infection may play a role in cell death and recovery of cells. }\end{array}$ \\
\hline VLDVR & $\begin{array}{l}\text { - Very low density lipoprotein/vitellogenin receptor } \\
\text { - Binds to baculovirus surface membrane to inhibit ligand-receptor interaction in viral infection of HeLa cells [43]. } \\
\text { - The meaning of down-regulation of VLDLR in ILTV vaccine infection in addition to in other herpesvirus infection, is unknown. }\end{array}$ \\
\hline $\mathrm{NMU}$ & $\begin{array}{l}\text { - Neuromedin } U \text {, a multifunctional neuropeptide } \\
\text { - Functions in conditions of pain and stress, the metabolism and homeostasis of feeding and energy in body, inflammatory } \\
\text { diseases, smooth muscle contraction, and the control of blood flow and pressure [44,45]. } \\
\text { - Induces early-phase inflammation through the degranulation in mast cells in which NMU-R1 is highly expressed [46]. } \\
\text { - Acts as an inflammatory mediator via the acceleration of IL-6 production in macrophages [47]. } \\
\text { - Down-regulation of NMU may represent the inhibition of cellular factors associated with inflammation. }\end{array}$ \\
\hline ADAM28 & $\begin{array}{l}\text { - A disintegrin and metalloproteinase (ADAM) domain } 28 . \\
\text { - Functions in cell-to-cell and cell-to-matrix interaction on the cell surface for cancer cell proliferation, invasion and metastasis } \\
{[48,49] \text {. }} \\
\text { - Up-regulated at carcinoma cells and functions the proliferation and progression of human lung and breast cancer cells [50,51]. } \\
\text { - Acts as an inhibitor against human dental pulp stem cells (HDPSCs) proliferation and an inducer of apoptosis of HDPSCs through } \\
\text { the stimulation of alkaline phosphatase (ALP) secretion and dentin sialophosphoprotein (DSPP) [52]. } \\
\text { - Degrades Insulin-like growth factor (IGF) binding protein } 3 \text { (IGFBP3) [53]. } \\
\text { - The decreased expression of ADAM28 in vaccine ILTV infection, may suppress the active induction of apoptosis. }\end{array}$ \\
\hline FST & $\begin{array}{l}\text { - Follistatin } \\
\text { - Inhibits follicle-stimulating hormone [54]. } \\
\text { - Binds and neutralizes activin, a paracrine hormone of TGF- } \beta \text { superfamily, which is related to the regulation of cell proliferation, } \\
\text { apoptosis, and carcinogenesis [55,56]. } \\
\text { - A member of fibrotic and wound healing response genes and cellular proliferation genes and plays a role in muscle growth and } \\
\text { strength in nonhuman primates and liver proliferation. Moreover, the small plaque mutant of VZV down-regulates FST [57]. } \\
\text { - Up-regulation of FST at early phase (1 dpi) of vaccine ILTV infection may play a role in the initiation of cytopathic effect. }\end{array}$ \\
\hline
\end{tabular}

diseases. NPY protects the nervous system from murine retrovirus-induced neurological disease [81]. The upregulation of NPY was observed in both infection and reactivation of VZV from a latent infection in human sensory trigeminal and dorsal ganglia, which are both sensory neurons [82]. It suggests that the up-regulation of NPY in virulent ILTV infection at 3 dpi may facilitate the latent infection in the nervous system. In contrast, the continuous down-regulation of NPY in vaccine ILTV infection may delay the latent infection to protect the host from diseases.

The coagulation factor, F10, is highly expressed during the early phase of SARS (severe acute respiratory syndrome) corona virus infection in human peripheral blood mononuclear cells (PBMCs) [83]. Expression of F10 in vaccine ILTV infections of lung cells increased at 1 - and $3 \mathrm{dpi}$, but the expression in virulent ILTV was not changed significantly at either 1- or 3dpi (Figure 5). A functional role of increased expression and secretion of F10 in vaccine herpesvirus infected lung cells has not been studied to date. The C8orf79 is an ORF region on chicken chromosome 8 , but its function is unknown.

\section{Conclusions}

In this study, we examined genome-wide host cellular transcriptomic changes by vaccine ILTV infection. 


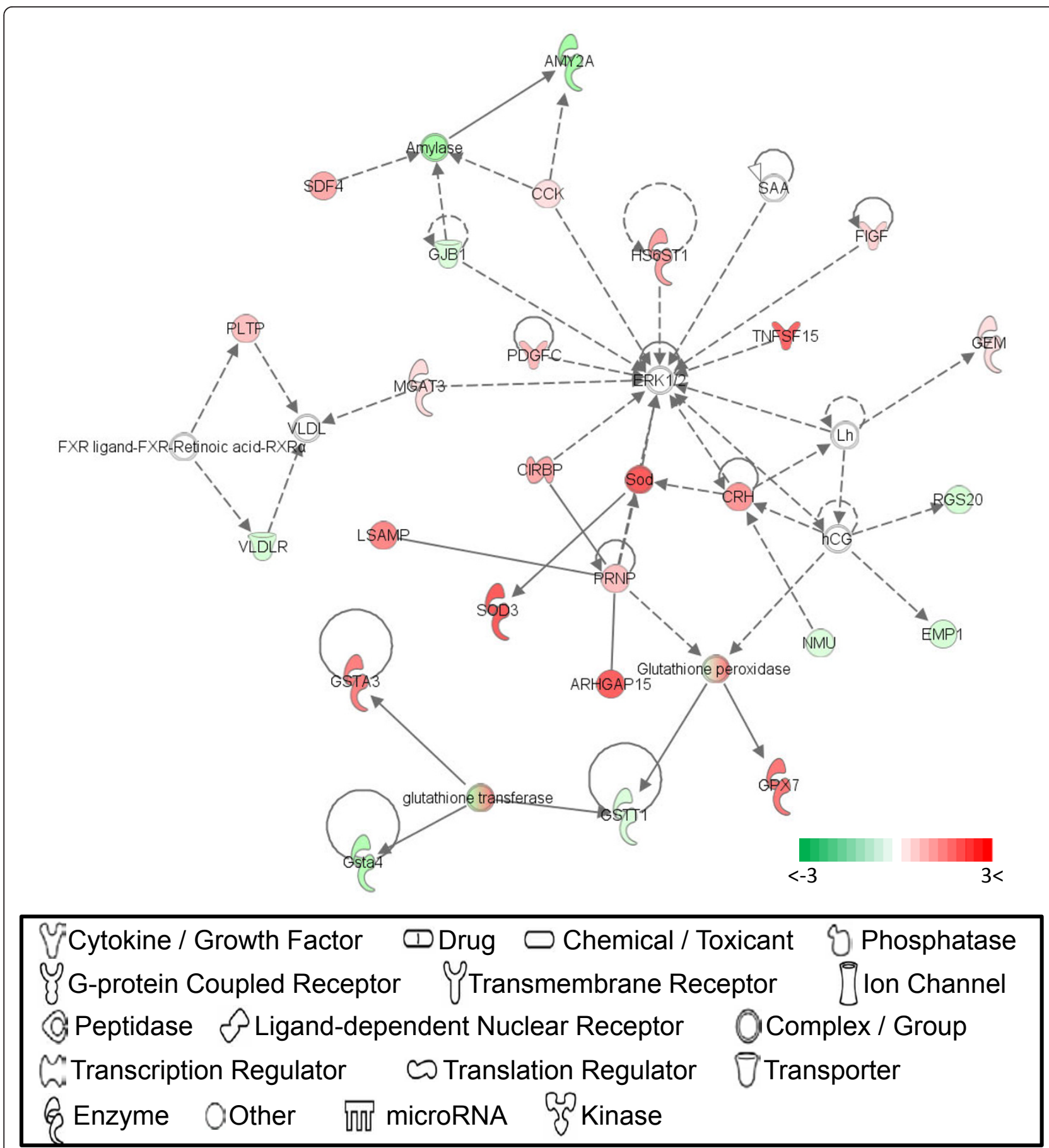

Figure 4 Network \#1 at 1 dpi. Symbols of functions for each molecule used to generate the molecular network are displayed. The green indicates down-regulation, while the red depicts up-regulation. White symbols indicate neighboring genes that are functionally associated but not included in the differentially expressed gene list. The intensity of color represents the average of $\log _{2}$ fold change in a given population. The numbers below the color change bar denote $\log _{2}$ values. Symbols for each molecule are presented according to molecular functions and type of interactions.

Unlike our previous research on virulent ILTV infection, the vaccine ILTV infection showed weak cytopathic effects, cellular morphology recovery after initial cytopathic effects were observed and very little cell death.
Possible molecular interpretations confirmed the suppression of cell death and weak cytopathic effect production during vaccine ILTV infection. Four host cellular genes were significantly modulated by vaccine 


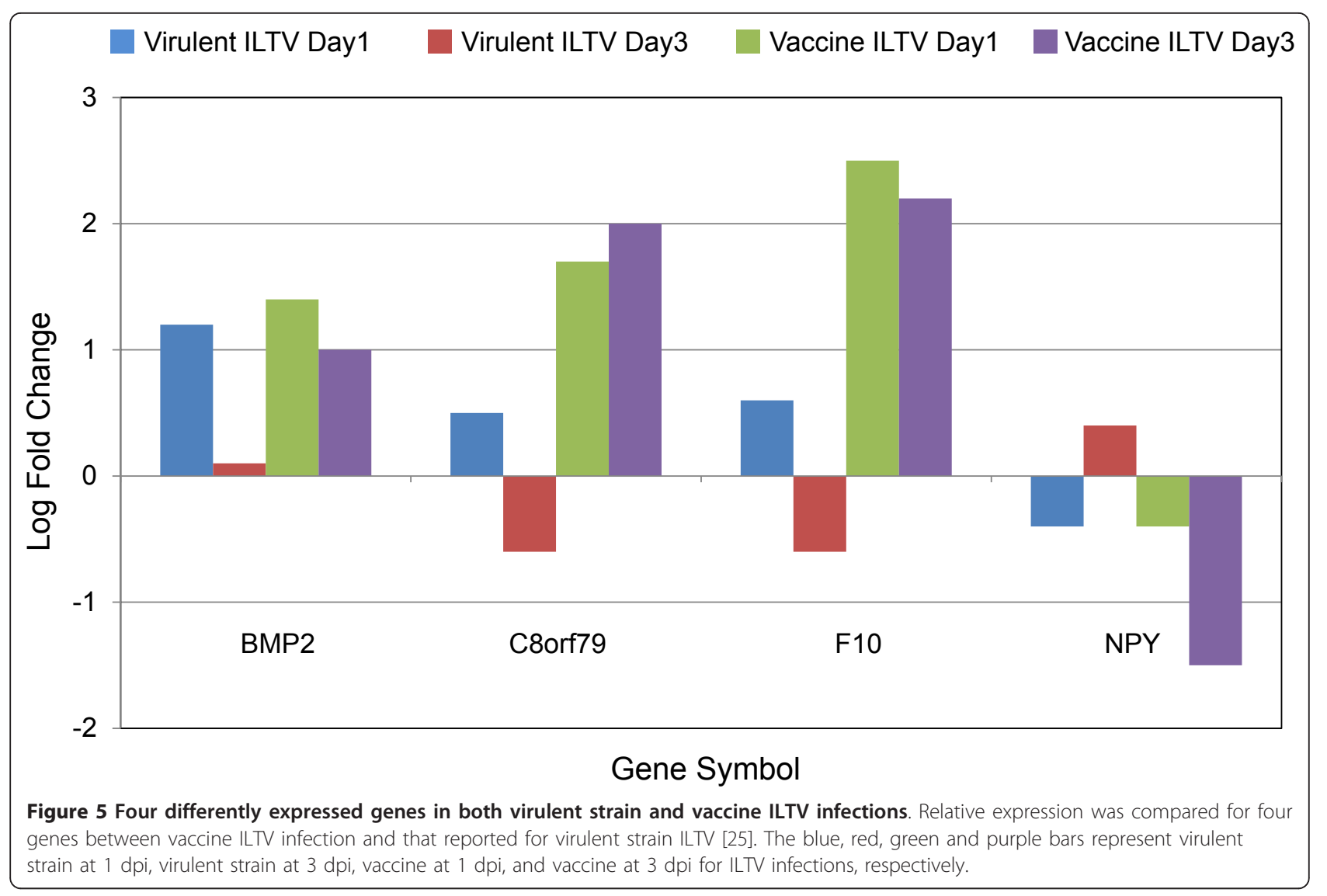

ILTV infection, and could represent important secreting regulators to protect cells from cytotoxic damages. Although host gene expression by vaccine ILTV infection was determined in a cell culture system and not by an in vivo vaccination study, the results in this study provide important insights into differential host cellular defense mechanisms by regulating host gene expression response of vaccine ILTV infection to compare those of virulent ILTV infection.

\section{Methods}

\section{Cell culture and vaccine ILTV infection}

Primary chicken embryo lung cells were prepared as previously described [25]. All cell culture reagents were purchased from Invitrogen Life Technologies (Carlsbad, CA). Cells were maintained at $37^{\circ} \mathrm{C}$ in a $5 \% \mathrm{CO}_{2}$ incubator in $10 \mathrm{~cm}$ culture dishes by passaging every 3-4 days in $10 \mathrm{ml}$ growth medium consisting Dulbecco's Modified Eagle Medium (DMEM, 0.45\% glucose) plus $10 \%$ fetal bovine serum (FBS), 100 units $/ \mathrm{ml}$ penicillin, $100 \mu \mathrm{g} / \mathrm{ml}$ streptomycin, and $2 \mathrm{mM}$ L-glutamine. A modified live ILTV commercial vaccine, LT-Blen (Merial Limited, Duluth, GA), was used to infect the chicken embryonic lung cells by the amount equal to 3 vaccination doses. After incubation of infected cells for $1 \mathrm{~h}$ with gentle rocking every $15 \mathrm{~min}$, growth medium was added to each culture dish. The cells were incubated for up to 4 days. The protocols used in this study were approved by both the Institutional Biosafety Committee (IBC; permit number: 10007) of the University of Arkansas and the Animal and Plant Health Inspection Service (APHIS; permit number: 102743) of the United States Department of Agriculture (USDA).

\section{Total RNA extraction}

TRIzol reagent (Invitrogen Life Technologies, Carlsbad, CA) was used to extract total RNA from uninfected- or vaccine ILTV infected chicken embryonic lung cells from 1 to 4 days post infection (dpi). Total RNA treated by DNase I (New England BioLabs Inc., Ipswich, MA) was repurified by TRIzol reagent and quantified using a Nanodrop1000 spectrophotometer (Thermo Scientific, Wilmington, DE) and qualified quality assessed by agarose gel (data not shown). To validate vaccine ILTV infection, expression of UL35 and US5 genes, in addition to chicken GAPDH (a host gene expression control), were determined by end-point reverse transcription PCR with gene specific primers. PCR amplicons were analyzed by agarose gel electrophoresis and images were obtained using the GelDoc system (Biorad, Hercules, CA). 


\section{Probe labeling and microarray hybridization}

Initially, $2 \mu \mathrm{g}$ of total RNA was used to synthesize Cy3 or Cy5 labeled complementary RNA (cRNA) using the Two Color Microarray Quick Labeling kit (Agilent Technologies, Palo Alto, CA) following the manufacturer's instructions and as described previously [25]. To avoid possible dye effects, RNA Spike-in controls, which were synthesized from the Adenovirus E1A transcriptomes containing different concentrations of dye in each set [33], were added to RNA samples as Spike-in A for Cy3 and Spike-in B for Cy5 and mixed with un-infected control and vaccine ILTV infected samples at each dpi, respectively. For the additional control of dye effects, the dyes were swapped in two of four total replicates to confirm further hidden dye effects. Each $825 \mathrm{ng}$ of Cy3 and $\mathrm{Cy} 5$ labeled cRNA probes were co-hybridized on a 4X44K Agilent chicken oligo microarray (array ID: 015068). After washing and drying, the slides were scanned using a Genepix 4000B scanner (Molecular Devices Corporation, Sunnyvale, CA) with the tolerance of saturation at $0.005 \%$.

\section{Microarray data analysis}

Background-corrected red and green intensities for each spot were used in subsequent analyses. Global normalization based on locally weighted linear regression (LOWESS) was applied to the intensities by removing effects which arise from undesirable systematic variations in microarray experiments. The ratio of signal intensities of corresponding spots to all Spike-ins used were compared to reference ratios reported previously [33]. All normalized data were deposited in the Gene Expression Omnibus (GEO; accession number: GSE30269). Genes showing both signal to noise ratio (SNR) of $>3$ (meaning foreground signals are three times greater than background signals), and foreground intensity of $>100$ at all time points were considered as reliable signals. To identify differentially expressed genes throughout the four dpi, normalized fold change values were subjected to statistical analysis by a one-way ANOVA test in JMP Genomics 5.0 http://www.jmp. com/software/genomics/ licensed to the Cell and Molecular Biology (CEMB) program of the University of Arkansas. Low fold change values, which were less than two fold differences in all four dpi, were not considered as differential expression. Fold change values representing differential expression were displayed as $\log _{2}$ conversions.

\section{Quantitative reverse transcription-polymerase Chain reaction (qPCR)}

To verify the microarray data, qPCR was performed with 18 genes using gene specific primer sets designed by Primer3 software http://frodo.wi.mit.edu/cgi-bin/ primer3/primer3.cgi, which were synthesized by Integrated DNA Technologies (Coralville, IA). Primer information is shown in Table 1 . Three $\mu \mathrm{g}$ of total RNA, which was used for the microarray analysis, was converted to $\mathrm{cDNA}$ and $\mathrm{qPCR}$ was performed under the following conditions: 40 cycles of denaturing $95^{\circ} \mathrm{C}$ for $30 \mathrm{~s}$, annealing at $58-62^{\circ} \mathrm{C}$ for $1 \mathrm{~min}$, extending at $72^{\circ}$ $\mathrm{C}$ for $30 \mathrm{~s}$, and finally extending at $72^{\circ} \mathrm{C}$ for $10 \mathrm{~min}$. A non-template control (NTC) and an endogenous loading control (chicken GAPDH) were used for the relative quantification. The fold change values for the vaccine ILTV infected groups compared to uninfected control were determined by the $-\Delta \Delta C T$ method, which is comparable to $\log _{2}$ values in microarray [84].

\section{Bioinformatics}

The Ingenuity Pathways Analysis (IPA) software version 9.0 (Ingenuity Systems ${ }^{\circledR}$; http://www.ingenuity.com) was used to study biological functions and molecular interactions among differentially expressed genes. IPA analyzes various bioinformatics tools including functional annotation, clustering, and network discovery based on Ingenuity Knowledge Base, which is the core technology of all IPA systems and the p-value developed from Right-tailed Fisher's exact test were mainly considered to interpret the interaction and functions of the differentially expressed genes $[85,86]$. The network analysis was limited to 10 networks and 35 molecules in each network to concentrate on the closest interacting focus molecules (focus genes $=$ a subset of uploaded significant genes having direct interactions with other genes in the database) within the differentially expressed genes [87].

\section{Additional material}

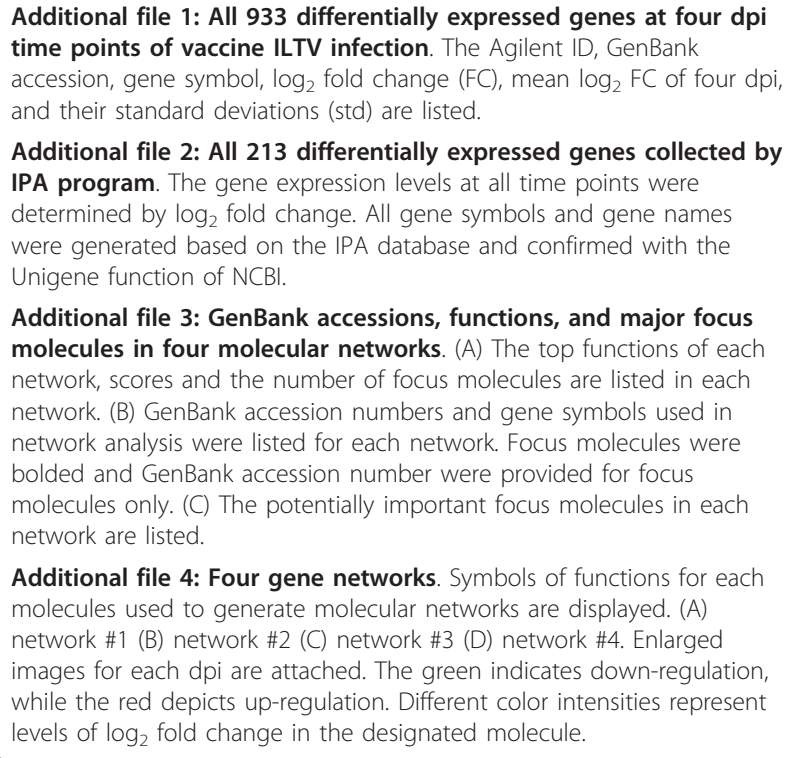


Additional file 5: The 21 genes showing a similar expression pattern in both virulent strain and vaccine ILTV infection.

\section{Acknowledgements}

We thank Dr. Douglas Foster (University of Minnesota) for the excellent comments in reviewing this manuscript. This work was supported, in part, by Arkansas Bioscience Institute, Arkansas Agricultural Experimental Station, and US Poultry and Egg Association (project \#640).

\section{Author details}

'Department of Poultry Science, Division of Agriculture, POSC O-404, 1260 West Maple, Fayetteville, AR 72701, USA. ${ }^{2}$ Cell and Molecular Biology Graduate Program, University of Arkansas, Fayetteville, AR 72701, USA.

\section{Authors' contributions}

$J Y L$ designed and performed experiments, analyzed the data, and wrote the manuscript. WB contributed the bioinformatics analysis using the IPA program and manuscript editing. BWK supervised all processes of the research, initial data analysis and manuscript editing. All authors read and approved the final manuscript.

\section{Competing interests}

The authors declare that they have no competing interests.

Received: 13 August 2011 Accepted: 24 April 2012

Published: 24 April 2012

\section{References}

1. Fuchs W, Veits J, Helferich D, Granzow H, Teifke JP, Mettenleiter TC: Molecular biology of avian infectious laryngotracheitis virus. Vet Res 2007, 38(2):261-279.

2. Lee SW, Markham PF, Markham JF, Petermann I, Noormohammadi AH, Browning GF, Ficorilli NP, Hartley CA, Devlin JM: First complete genome sequence of infectious laryngotracheitis virus. BMC Genomics 2011, 12:197.

3. Bankowski RA, Corstvet RE, Clark GT: Isolation of an unidentified agent from the respiratory tract of chickens. Science 1960, 132:292-293.

4. Crawshaw GJ, Boycott BR: Infectious laryngotracheitis in peafowl and pheasants. Avian Dis 1982, 26(2):397-401.

5. Bagust TJ, Jones RC, Guy JS: Avian infectious laryngotracheitis. Rev Sci Tech 2000, 19(2):483-492.

6. Knipe DM, Howley PM: Herpes Simplex Viruses. Fields Virology , 5 2007, 2501-2061.

7. Rodriguez-Avila A, Oldoni I, Riblet S, Garcia M: Replication and transmission of live attenuated infectious laryngotracheitis virus (ILTV) vaccines. Avian Dis 2007, 51(4):905-911.

8. Hughes CS, Williams RA, Gaskell RM, Jordan FT, Bradbury JM, Bennett M, Jones RC: Latency and reactivation of infectious laryngotracheitis vaccine virus. Arch Virol 1991, 121(1-4):213-218.

9. Guy JS, Barnes HJ, Smith L: Increased virulence of modified-live infectious laryngotracheitis vaccine virus following bird-to-bird passage. Avian Dis 1991, 35(2):348-355.

10. Meyer HM Jr, Hopps HE, Parkman PD: Appraisal and reappraisal of viral vaccines. Adv Intern Med 1980, 25:533-560

11. Guy JS, Barnes HJ, Munger LL, Rose L: Restriction endonuclease analysis of infectious laryngotracheitis viruses: comparison of modified-live vaccine viruses and North Carolina field isolates. Avian Dis 1989, 33(2):316-323.

12. Keeler CL Jr, Hazel JW, Hastings JE, Rosenberger JK: Restriction endonuclease analysis of Delmarva field isolates of infectious laryngotracheitis virus. Avian Dis 1993, 37(2):418-426.

13. Oldoni I, Garcia M: Characterization of infectious laryngotracheitis virus isolates from the US by polymerase chain reaction and restriction fragment length polymorphism of multiple genome regions. Avian Pathol 2007, 36(2):167-176.

14. Khalid SS, Hamid S, Siddiqui AA, Qureshi A, Qureshi N: Gene profiling of early and advanced liver disease in chronic hepatitis $C$ patients. Hepatol Int 2011, 5(3):782-788.
15. Satoh K, Shimizu T, Kondoh H, Hiraguri A, Sasaya T, Choi IR, Omura T, Kikuchi S: Relationship between symptoms and gene expression induced by the infection of three strains of Rice dwarf virus. PLOS One 2011, 6(3): e18094.

16. Mukherjee S, Vipat VC, Mishra AC, Pawar SD, Chakrabarti AK: Pandemic (H1N1) 2009 influenza virus induces weaker host immune responses in vitro: a possible mechanism of high transmissibility. Virol J 2011, 8:140.

17. Alberter B, Vogel B, Lengenfelder D, Full F, Ensser A: Genome-wide histone acetylation profiling of Herpesvirus saimiri in human $T$ cells upon induction with a histone deacetylase inhibitor. J Virol 2011, 85(11):5456-5464.

18. de la Fuente C, Santiago F, Deng L, Eadie C, Zilberman I, Kehn K, Maddukuri A, Baylor S, Wu K, Lee CG, Pumfery A, Kashanchi F: Gene expression profile of HIV-1 Tat expressing cells: a close interplay between proliferative and differentiation signals. BMC Biochem 2002, 3:14.

19. Wu JQ, Dwyer DE, Dyer WB, Yang YH, Wang B, Saksena NK: Genome-wide analysis of primary CD4+ and CD8+ T cell transcriptomes shows evidence for a network of enriched pathways associated with HIV disease. Retrovirology 2011, 8:18.

20. Gupta N, Bhaskar AS, Lakshmana Rao PV: Transcriptional regulation and activation of the mitogen-activated protein kinase pathway after Japanese encephalitis virus infection in neuroblastoma cells. FEMS Immunol Med Microbiol 2011, 62(1):110-121.

21. Yang $Y, Y$, J, Yang $X$, Jiang $R$, Chen $H$, Cao S: Japanese encephalitis virus infection induces changes of mRNA profile of mouse spleen and brain. Virol J 2011, 8:80.

22. Crowley TM, Haring VR, Moore R: Chicken anemia virus: an understanding of the in-vitro host response over time. Viral Immunol 2011, 24(1):3-9.

23. Hertoghs KM, Moerland PD, van Stijn A, Remmerswaal EB, Yong SL, van de Berg PJ, van Ham SM, Baas F, ten Berge IJ, van Lier RA: Molecular profiling of cytomegalovirus-induced human CD8+ T cell differentiation. J Clin Invest 2010, 120(11):4077-4090.

24. Ye J, Gradoville L, Miller G: Cellular immediate-early gene expression occurs kinetically upstream of Epstein-Barr virus bzlf1 and brlf1 following cross-linking of the $B$ cell antigen receptor in the Akata Burkitt lymphoma cell line. J Virol 2010, 84(23):12405-12418.

25. Lee JY, Song JJ, Wooming A, Li X, Zhou H, Bottje WG, Kong BW: Transcriptional profiling of host gene expression in chicken embryo lung cells infected with laryngotracheitis virus. BMC Genomics 2010, 11:445.

26. Ashrafi GH, Grinfeld E, Montague P, Forster T, Ross A, Ghazal P, Scott F, Breuer J, Goodwin R, Kennedy PG: Assessment of transcriptomal analysis of Varicella-Zoster-virus gene expression in patients with and without post-herpetic neuralgia. Virus Genes 2010, 41(2):192-201.

27. Szpara ML, Kobiler O, Enquist LW: A common neuronal response to alphaherpesvirus infection. J Neuroimmune Pharmacol 2010, 5(3):418-427.

28. Kano R, Konnai S, Onuma M, Ohashi K: Microarray analysis of host immune responses to Marek's disease virus infection in vaccinated chickens. J Vet Med Sci 2009, 71(5):603-610.

29. Clement C, Popp MP, Bloom DC, Schultz G, Liu L, Neumann DM, Bhattacharjee PS, Hill JM: Microarray analysis of host gene expression for comparison between naive and HSV-1 latent rabbit trigeminal ganglia. Mol Vis 2008, 14:1209-1221.

30. Bidzhieva B, Laassri M, Chumakov K: MAPREC assay for quantitation of mutants in a recombinant flavivirus vaccine strain using near-infrared fluorescent dyes. J Virol Methods 2011, 175(1):14-19.

31. Laassri M, Bidzhieva B, Speicher J, Pletnev AG, Chumakov K: Microarray hybridization for assessment of the genetic stability of chimeric West Nile/dengue 4 virus. J Med Virol 2011, 83(5):910-920.

32. Balas C, Kennel A, Deauvieau F, Sodoyer R, Arnaud-Barbe N, Lang J, Guy B: Different innate signatures induced in human monocyte-derived dendritic cells by wild-type dengue 3 virus, attenuated but reactogenic dengue 3 vaccine virus, or attenuated nonreactogenic dengue 1-4 vaccine virus strains. J Infect Dis 2011, 203(1):103-108.

33. Zahurak M, Parmigiani G, Yu W, Scharpf RB, Berman D, Schaeffer E, Shabbeer S, Cope L: Pre-processing Agilent microarray data. BMC Bioinforma 2007, 8:142.

34. Bitoun E, Micheloni A, Lamant L, Bonnart C, Tartaglia-Polcini A, Cobbold C, Al Saati T, Mariotti F, Mazereeuw-Hautier J, Boralevi F, Hohl D, Harper J, Bodemer C, D'Alessio M, Hovnanian A: LEKTI proteolytic processing in human primary keratinocytes, tissue distribution and defective 
expression in Netherton syndrome. Hum Mol Genet 2003, 12(19):2417-2430.

35. Streit $M$, Riccardi $L$, Velasco $P$, Brown LF, Hawighorst $T$, Bornstein $P$, Detmar M: Thrombospondin-2: a potent endogenous inhibitor of tumor growth and angiogenesis. Proc Natl Acad Sci USA 1999, 96(26):14888-14893.

36. Metodieva SN, Nikolova DN, Cherneva RV, Dimova II, Petrov DB, Toncheva DI: Expression analysis of angiogenesis-related genes in Bulgarian patients with early-stage non-small cell lung cancer. Tumori 2011, 97(1):86-94.

37. Miragliotta V, Raphael K, Ipina Z, Lussier JG, Theoret CL: Equine thrombospondin II and secreted protein acidic and cysteine-rich in a model of normal and pathological wound repair. Physiol Genomics 2009, 38(2):149-157.

38. Halestrap AP: What is the mitochondrial permeability transition pore? J Mol Cell Cardiol 2009, 46(6):821-831.

39. Baines CP: The molecular composition of the mitochondrial permeability transition pore. J Mol Cell Cardiol 2009, 46(6):850-857.

40. Green DR, Reed JC: Mitochondria and apoptosis. Science 1998, 281(5381):1309-1312.

41. Zamzami N, Susin SA, Marchetti P, Hirsch T, Gomez-Monterrey I, Castedo M, Kroemer G: Mitochondrial control of nuclear apoptosis. J Exp Med 1996, 183(4):1533-1544.

42. Marchetti P, Castedo M, Susin SA, Zamzami N, Hirsch T, Macho A, Haeffner A, Hirsch F, Geuskens M, Kroemer G: Mitochondrial permeability transition is a central coordinating event of apoptosis. J Exp Med 1996, 184(3):1155-1160.

43. Marlovits TC, Abrahamsberg C, Blaas D: Very-low-density lipoprotein receptor fragment shed from HeLa cells inhibits human rhinovirus infection. J Virol 1998, 72(12):10246-10250.

44. Budhiraja S, Chugh A: Neuromedin U: physiology, pharmacology and therapeutic potential. Fundam Clin Pharmacol 2009, 23(2):149-157.

45. Novak CM: Neuromedin S and U. Endocrinology 2009, 150(7):2985-2987.

46. Moriyama M, Sato T, Inoue H, Fukuyama S, Teranishi H, Kangawa K, Kano T, Yoshimura A, Kojima M: The neuropeptide neuromedin $\mathrm{U}$ promotes inflammation by direct activation of mast cells. J Exp Med 2005, 202(2):217-224.

47. Moriyama M, Matsukawa A, Kudoh S, Takahashi T, Sato T, Kano T, Yoshimura A, Kojima M: The neuropeptide neuromedin U promotes IL-6 production from macrophages and endotoxin shock. Biochem Biophys Res Commun 2006, 341(4):1149-1154.

48. Howard L, Maciewicz RA, Blobel CP: Cloning and characterization of ADAM28: evidence for autocatalytic pro-domain removal and for cell surface localization of mature ADAM28. Biochem J 2000, 348(Pt 1):21-27.

49. Mochizuki S, Okada Y: ADAM28: involvement in cancer cell proliferation, invasion and metastasis. Seikagaku 2010, 82(10):940-949.

50. Ohtsuka T, Shiomi T, Shimoda M, Kodama T, Amour A, Murphy G, Ohuchi E, Kobayashi K, Okada Y: ADAM28 is overexpressed in human non-small cell lung carcinomas and correlates with cell proliferation and lymph node metastasis. Int J Cancer 2006, 118(2):263-273.

51. Mitsui $Y$, Mochizuki S, Kodama T, Shimoda M, Ohtsuka T, Shiomi T, Chijiiwa M, Ikeda T, Kitajima M, Okada Y: ADAM28 is overexpressed in human breast carcinomas: implications for carcinoma cell proliferation through cleavage of insulin-like growth factor binding protein-3. Cancer Res 2006, 66(20):9913-9920.

52. Zhao Z, Liu HC, Huang ZN: Effects of ADAM28 AS-ODN on proliferation, differentiation and apoptosis of HPDLSC. Shanghai Kou Qiang Yi Xue 2009, 18(5):524-531.

53. Mochizuki S, Shimoda M, Shiomi T, Fujii Y, Okada Y: ADAM28 is activated by MMP-7 (matrilysin-1) and cleaves insulin-like growth factor binding protein-3. Biochem Biophys Res Commun 2004, 315(1):79-84.

54. Ueno N, Ling N, Ying SY, Esch F, Shimasaki S, Guillemin R: Isolation and partial characterization of follistatin: a single-chain $\mathrm{Mr} 35,000$ monomeric protein that inhibits the release of follicle-stimulating hormone. Proc Natl Acad Sci USA 1987, 84(23):8282-8286.

55. Thompson TB, Lerch TF, Cook RW, Woodruff TK, Jardetzky TS: The structure of the follistatin:activin complex reveals antagonism of both type I and type II receptor binding. Dev Cell 2005, 9(4):535-543.

56. Chen YG, Lui HM, Lin SL, Lee JM, Ying SY: Regulation of cell proliferation, apoptosis, and carcinogenesis by activin. Exp Biol Med (Maywood) 2002, 227(2):75-87
57. Jones JO, Arvin AM: Viral and cellular gene transcription in fibroblasts infected with small plaque mutants of varicella-zoster virus. Antiviral Res 2005, 68(2):56-65.

58. May HG, Tittsler RP: Tracheolaryngotracheitis in poultry. J Am Vet Med Assoc 1925, 67:229-231.

59. Weigert J, Neumeier M, Schaffler A, Fleck M, Scholmerich J, Schutz C, Buechler C: The adiponectin paralog CORS-26 has anti-inflammatory properties and is produced by human monocytic cells. FEBS Lett 2005 579(25):5565-5570.

60. Weigert C, Hennige AM, Brodbeck K, Haring HU, Schleicher ED: Interleukin6 acts as insulin sensitizer on glycogen synthesis in human skeletal muscle cells by phosphorylation of Ser473 of Akt. Am J Physiol Endocrinol Metab 2005, 289(2):E251-257.

61. Wolfing B, Buechler C, Weigert J, Neumeier M, Aslanidis C, Schoelmerich J, Schaffler A: Effects of the new C1q/TNF-related protein (CTRP-3) "cartonectin" on the adipocytic secretion of adipokines. Obesity (Silver Spring) 2008, 16(7):1481-1486.

62. Botto S, Streblow DN, DeFilippis V, White L, Kreklywich CN, Smith PP, Caposio P: IL-6 in human cytomegalovirus secretome promotes angiogenesis and survival of endothelial cells through the stimulation of survivin. Blood 2011, 117(1):352-361.

63. Kong BW, Song JJ, Lee JY, Hargis BM, Wing T, Lassiter K, Bottje W: Gene expression in breast muscle associated with feed efficiency in a single male broiler line using a chicken $44 \mathrm{~K}$ oligo microarray. I Top differentially expressed genes Poult Sci 2011, 90(11):2535-2547.

64. Zhang ZQ, Song YL, Chen ZH, Shen Y, Bai CX: Deletion of Aquaporin 5 Aggravates Acute Lung Injury Induced by Pseudomonas aeruginosa. J Trauma 2011, 71(5):1305-1311.

65. Shankardas J, Patil RV, Vishwanatha JK: Effect of down-regulation of aquaporins in human corneal endothelial and epithelial cell lines. Mol Vis 2010, 16:1538-1548.

66. Towne JE, Harrod KS, Krane CM, Menon AG: Decreased expression of aquaporin (AQP)1 and AQP5 in mouse lung after acute viral infection. Am J Respir Cell Mol Biol 2000, 22(1):34-44.

67. Jensen RT, Wank SA, Rowley WH, Sato S, Gardner JD: Interaction of CCK with pancreatic acinar cells. Trends Pharmacol Sci 1989, 10(10):418-423.

68. Gukovskaya AS, Gukovsky I, Jung Y, Mouria M, Pandol SJ: Cholecystokinin induces caspase activation and mitochondrial dysfunction in pancreatic acinar cells. Roles in cell injury processes of pancreatitis. $J$ Biol Chem 2002, 277(25):22595-22604.

69. Vlahakis NE, Young BA, Atakilit A, Sheppard D: The lymphangiogenic vascular endothelial growth factors VEGF-C and -D are ligands for the integrin alpha9beta1. J Biol Chem 2005, 280(6):4544-4552.

70. Wen $L$, Zhuang L, Luo X, Wei P: TL1A-induced NF-kappaB activation and c-IAP2 production prevent DR3-mediated apoptosis in TF-1 cells. J Biol Chem 2003, 278(40):39251-39258.

71. Refojo D, Echenique C, Muller MB, Reul JM, Deussing JM, Wurst W, Sillaber I, Paez-Pereda M, Holsboer F, Arzt E: Corticotropin-releasing hormone activates ERK1/2 MAPK in specific brain areas. Proc Natl Acad Sci USA 2005, 102(17):6183-6188.

72. Campbell JS, Hughes SD, Gilbertson DG, Palmer TE, Holdren MS, Haran AC, Odell MM, Bauer RL, Ren HP, Haugen HS, Yeh MM, Fausto N: Plateletderived growth factor $C$ induces liver fibrosis, steatosis, and hepatocellular carcinoma. Proc Natl Acad Sci USA 2005, 102(9):3389-3394.

73. Sato Y, Takahashi M, Shibukawa Y, Jain SK, Hamaoka R, Miyagawa J, Yaginuma $Y$, Honke K, Ishikawa M, Taniguchi N: Overexpression of $\mathrm{N}$ acetylglucosaminyltransferase III enhances the epidermal growth factorinduced phosphorylation of ERK in HeLaS3 cells by up-regulation of the internalization rate of the receptors. J Biol Chem 2001, 276(15):11956-11962

74. Sugaya N, Habuchi H, Nagai N, Ashikari-Hada S, Kimata K: 6-O-sulfation of heparan sulfate differentially regulates various fibroblast growth factordependent signalings in culture. J Biol Chem 2008, 283(16):10366-10376.

75. Artero-Castro A, Callejas FB, Castellvi J, Kondoh H, Carnero A, FernandezMarcos PJ, Serrano M, Ramon Y, Cajal S, Lleonart ME: Cold-inducible RNAbinding protein bypasses replicative senescence in primary cells through extracellular signal-regulated kinase 1 and 2 activation. Mol Cell Biol 2009, 29(7):1855-1868.

76. Kuhn H, Borchert A: Regulation of enzymatic lipid peroxidation: the interplay of peroxidizing and peroxide reducing enzymes. Free Radic Biol Med 2002, 33(2):154-172. 
77. Blitz IL, Cho KW: Finding partners: how BMPs select their targets. Dev Dyn 2009, 238(6):1321-1331

78. Blanco Calvo M, Bolos Fernandez V, Medina Villaamil V, Aparicio Gallego G Diaz Prado S, Grande Pulido E: Biology of BMP signalling and cancer. Clin Transl Oncol 2009, 11(3):126-137.

79. Yin Q, Wang X, Fewell C, Cameron J, Zhu H, Baddoo M, Lin Z, Flemington EK: MicroRNA miR-155 inhibits bone morphogenetic protein (BMP) signaling and BMP-mediated Epstein-Barr virus reactivation. J Virol 2010, 84(13):6318-6327.

80. Cotter EJ, IP HS, Powderly WG, Doran PP: Mechanism of HIV protein induced modulation of mesenchymal stem cell osteogenic differentiation. BMC Musculoskelet Disord 2008, 9:33.

81. Du M, Butchi NB, Woods T, Morgan TW, Peterson KE: Neuropeptide $Y$ has a protective role during murine retrovirus-induced neurological disease. J Virol 2010, 84(21):11076-11088.

82. Garry EM, Delaney A, Anderson HA, Sirinathsinghji EC, Clapp RH, Martin WJ, Kinchington PR, Krah DL, Abbadie C, Fleetwood-Walker SM: Varicella zoster virus induces neuropathic changes in rat dorsal root ganglia and behavioral reflex sensitisation that is attenuated by gabapentin or sodium channel blocking drugs. Pain 2005, 118(1-2):97-111.

83. Ng LF, Hibberd ML, Ooi EE, Tang KF, Neo SY, Tan J, Murthy KR, Vega VB, Chia JM, Liu ET, Ren EC: A human in vitro model system for investigating genome-wide host responses to SARS coronavirus infection. BMC Infect Dis 2004, 4:34.

84. Livak KJ, Schmittgen TD: Analysis of relative gene expression data using real-time quantitative PCR and the 2(-Delta Delta C(T)) Method. Methods 2001, 25(4):402-408.

85. Fisher RA: On the interpretation of $\mathrm{X} 2$ from contingency tables, and the calculation of P. J R Stat Soc 1922, 85(1):87-94.

86. Mori R, Xiong S, Wang Q, Tarabolous C, Shimada H, Panteris E, Danenberg KD, Danenberg PV, Pinski JK: Gene profiling and pathway analysis of neuroendocrine transdifferentiated prostate cancer cells. Prostate 2009, 69(1):12-23.

87. Calvano SE, Xiao W, Richards DR, Felciano RM, Baker HV, Cho RJ, Chen RO, Brownstein BH, Cobb JP, Tschoeke SK, Miller-Graziano C, Moldawer LL, Mindrinos MN, Davis RW, Tompkins RG, Lowry SF: Inflamm and Host Response to Injury Large Scale Collab. Res. Program: A network-based analysis of systemic inflammation in humans. Nature 2005, 437(7061):1032-1037.

doi:10.1186/1471-2164-13-143

Cite this article as: Lee et al:: Genome-wide host responses against infectious laryngotracheitis virus vaccine infection in chicken embryo lung cells. BMC Genomics 2012 13:143.

\section{Submit your next manuscript to BioMed Central and take full advantage of:}

- Convenient online submission

- Thorough peer review

- No space constraints or color figure charges

- Immediate publication on acceptance

- Inclusion in PubMed, CAS, Scopus and Google Scholar

- Research which is freely available for redistribution 